\title{
Kamu Politikalarına Karar Verme Sürecini Yol Bă̆ımlılı̆̆ı Ekseninde Yeniden Düşünme
}

\author{
Rethinking on Decision Making Process of Public Policies From The Point of View of \\ Path Dependence
}

Sema Müge ÖZDEMIRAY*

$\ddot{O} Z$

Kamu politikası; ilgili literatürde üzerinde uzlaşı sağlanmış bir tanımı bulunmayan ancak vatandaşların ihtiyaçlarını gidermek, çeşitli toplumsal sorunları çözüme ulaştırmak amacıyla siyasi aktörler tarafindan yapılan tercihlerin belirleyici olduğu karmaşık bir sürecin ürünüdür. Pek çok içsel ve dlşsal faktörün etkisinde oluşan kamu politikaları ile ilgili olarak karar verme aşamasında etkili olan aktörlerin kimler olduğu sorusu kadar, aktörlerin tercihinde etkili olan unsurların neler olduğu sorusu da önem arz etmektedir. Nitekim günümüzün karmaşık ortamında siyasi karar vericilerin rasyonel bir şekilde, belirli standartlar çerçevesinde en iyi ya da en uygun alternatifi tercih edeceği savi sorgulanır hale gelmişstir. Bu doğrultuda çalışmanın amacı, kamu politikalarına karar verme sürecinde aktörlerin tercihlerine etki eden unsurlara dair yapılacak değerlendirmelerde, en temel haliyle geçmişte yapılan tercihlerin gelecekteki tercih ve kararlar üzerindeki belirleyiciliğine vurgu yapan yol bağımlıllğı olgusunun kullanılabilirliğine yönelik literatüre dayalı betimsel bir araştırma yapmaktır. Çalışmada; yol bağımlılı̆̆ olgusunu ilgili aktörlerin yapacakları tercihlerde inceledikleri alternatifleri sinırlandıran bir olgu olarak negatif şekilde değerlendirmenin mümkün olduğu kadar, karmaşı bir alanda faaliyet gösteren siyasi aktörler açısından karmaşıkllğın azaltılması ve farklı tercihlerde bulunmanın alternatif maliyeti dolayısıyla olumlu sonuçlar üreteceği şseklinde değerlendirmenin de mümkün olduğu sonucuna ulaşılmıştır. Kolektif bir sürecin ürünü olan kamu politikaları açısından yol bağımlılığı olasılı̆̆ının her zaman olduğu ve kamu politikalarına karar verme süreci incelenirken artılarl ve eksileri ile bu olgunun göz ardı edilmemesinin gerekliliği de ortaya konulmuştur.

ANAHTAR KELIMELER

Yol Bağımlılı̆̆ı, Kamu Politikası, Karar Verme Süreci, Tarihsel Kurumsalcılık

\begin{abstract}
Public policy is an output of a complicated process which is determined by the preferences of political actors that does not have an agreed definition in the literature that aims to solve various social issues and meet the needs of citizens. The question of what are the factors that are influential in the actors' preference is as important as the question of who are the actors in the decision-making process of public policies that are influenced by many internal and external factors. As a matter of fact, in today's complex environment, the argument that political decision-makers will rationally choose the best or most appropriate alternative within the framework of certain standards has become questionable. The aim of this study is to make a descriptive research based on the literature on the usability of path dependence -which is defined in the most basic form as the choices made in the past are decisive on future choices and decisions- in evaluating the factors affecting the preferences of the actors in the decision making process of public policies. In this study, it is concluded that it is possible to evaluate path dependence in a negative way as it limits the alternatives that the relevant actors examine in the choices they will make, and in a positive way due to the reduction of complexity and the alternative cost of making different choices for political actors operating in a complex field. Noteworthy; this is the fact that there is always the possibility of path dependence in terms of public policies which are the product of a collective process, and that this phenomenon is not to be ignored with its pros and cons when examining the decision-making process of public policies.
\end{abstract}

\section{KEYWORDS}

Path Dependence, Public Policy, Decision- Making Process, Historical Institutionalism

\begin{tabular}{|c|c|c|}
\hline \multicolumn{2}{|c|}{ Makale Geliş Tarihi / Submission Date } & \multicolumn{1}{c|}{$\begin{array}{c}\text { Makale Kabul Tarihi / Date of Acceptance } \\
25.04 .2020\end{array}$} \\
\hline \multirow{3}{*}{ Atıf } & \multicolumn{2}{|c|}{$\begin{array}{l}\text { Özdemiray, S.M. (2020). Kamu Politikalarına Karar Verme Sürecini Yol Bağımlılı̆̆ Ekseninde Yeniden Düşünme. } \\
\text { Selçuk Üniversitesi Sosyal Bilimler Meslek Yüksekokulu Dergisi, 23 (1), 318-325. }\end{array}$} \\
\hline
\end{tabular}

\footnotetext{
* Dr. Öğr. Üyesi, Necmettin Erbakan Üniversitesi Siyasal Bilgiler Fakültesi Siyaset Bilimi ve Kamu Yönetimi Bölümü, smozdemiray@erbakan.edu.tr, ORCID: 0000-0003-0786-8382
} 


\section{GİRIŞ}

Örgütlenmiş her topluluk belirli bir amaca sahiptir ve amaçlarına ulaşabilmek için ise çeşitli kararlar almak yükümlüğündedir. Benzer şekilde kamu yönetimleri de kamu hizmetlerinin etkin bir şekilde yürütülmesi amacıyla kamu politikası olarak adlandırılan pek çok karar alır. Kamu yönetiminin görevlerini gereğince yerine getirebilmesi ve toplum nezdinde meşruiyetlerinin devamını temin edebilmesi karar verilen kamu politikalarının değeriyle doğru orantılıdır. Birbiriyle ilişkili pek çok unsurun bileşimi sonucunda oluşan kamu politikalarına karar verme süreci ise başlı başına karmaşı bir süreçtir.

Geçmişle, şu anla ve gelecekle bağlantılı çok boyutlu bir olgu olan karar verme konusunda literatürde "rasyonel karar verme modelleri" şeklinde nitelenen pek çok reçete sunulmakla birlikte bu reçetelerin kamu yönetimleri için her zaman arzulanan sonuçları üretebileceğini söylemek zordur. Bir diğer ifadeyle rasyonel seçim teorisinin öngördüğü şekilde bireylerin tercih yapmak durumunda kaldıklarında en iyi ya da en uygunu tercih edecekleri kabulü özellikle kamu politikaları gibi sınırlı zamanda, sürece dahil olan pek çok unsurun etkisiyle karmaşı ve geniş ilişki ağları içerisinde karar vermek durumunda olan aktörler için sorgulanır hale gelmiştir. Tarihsel kurumsalcılığın temel varsayımlarından biri olan ve en basit haliyle geçmişte yapılan tercihlerin gelecekteki tercihler üzerinde oluşturacağı baskı şeklinde tanımlanabilecek yol bağımlılığı olgusu, hem aktörlerin rasyonelliğini sınırlandıran bir olgu olarak değerlendirilebilecek hem de kamu politikalarının gelişimini anlama noktasında başvurulabilecek çekici varsayımlardan bir tanesidir. Bu doğrultuda çalışmanın amacı; çoğunlukla kamu politikaları alanında reform gerçekleştirmenin neden zor olduğu sorusuna verilen cevaplarda atıf yapılan bir olgu olan yol bağımlılı̆g olgusunun kamu politikalarına karar verme sürecinde özellikle bireysel rasyonellik ihlallerini açıklamada da kullanılabilirliğinin tartışılmasıdır. Bu amaç doğrultusunda yol bağımlılığının varsayımlarının ve sınırlarının ortaya konulması gerekmektedir. Dolayısıyla çalışmada öncelikle karar vermenin ve yol bağımlılı̆̆ının kavramsal çerçevesi çizilmeye çalışılmış daha sonra ise kamu politikalarına karar verme sürecinde siyasi yetkililerin tercihlerine etki eden unsurları anlamada yol bağımlılığının yerine dair çıkarımda bulunma amacı doğrultusunda konu hakkında gerçekleştirilen literatür taraması neticesinde elde edilen bilgilere yer verilerek bir sonuca varılmıştır. Kolektif bir sürecin ürünü olan kamu politikalarına karar verme sürecine dahil olan bireylerin yaptıkları tercihlerde - özellikle bilinç dışı tercihlerde- var olan bir yol bağımlılığının bireylerde farkındalık yaratmadan, bilişlerinden haberdar etmeden ve yapacakları tercihler üzerinde etkili olmadan ortaya konulmasının zorluğu konu ile ilgili önemli bir sinirliliktır.

\section{KARAR VERME OLGUSU VE YOL BAĞIMLILIĞI}

Karar verme; insan, aile, toplum, birlik, örgüt gibi her türlü bireysel, sosyal ya da kurumsal yapı açısından en çok icra edilen faaliyettir (Çevik, 2016: 161). Siyasetin ve kamu yönetiminin doğası gereği kalbinin attığ1 yerde gerçekleşen dinamik bir süreçtir (Kutlu ve Özdemiray, 2016: 79). Toplumdan aldığı yetki ile kamu yararını gözeterek toplumu ilgilendiren kilit kararları vermekle yükümlü kamu yöneticileri tarafından yapılan tercihler hayatın her alanında etkilidir. Nitekim bu tercihler sonucunda oluşan kararlar geçmişle, şu anla ve gelecekle bağlantılı olarak çok boyutlu bir sürecin ürünüdür (Önder, 2012: 1). Karar verme olarak adlandırılan bu süreç ise "mevcut koşullarda değişimler yaratmayı, alternatif eylem biçimlerinden birini seçmeyi, kararı uygulayabilmek için örgütsel ve bireysel kaynaklarda genişlemeyi ve arzulanan sonuçlara varılması beklentisiyle eylemde bulunmayı" içerir (Ergun, 2004: 121). Karar verme sürecini açıklamak için öne sürülen farklı yaklaşımlar bulunmaktadır. Günümüzde çok sayıda farklı sınıflandırma bulunsa da rasyonel model, karar verme sürecini açıklamada başvurulan en temel model olmuştur. Rasyonel modele göre karar verme belirli aşamalardan oluşan bir süreçtir. Bunlar; bir sorunun ya da gereksinimin varlığının tespiti, hedeflerin belirlenmesi, alternatif seçeneklerin oluşturulması ve değerlendirilmesi, seçenekler arasından seçim yapılması, uygulama ve geri beslemedir. Bütün bu süreçte amaç, elde edilebilecek maksimum faydayı sağlamaktır (Çevik, 2016: 162). Karar verici ise karar verme öncesinde tüm alternatifleri ve sonuçlarını bilmekte, tespit ettiğgi alternatifleri yarar seviyesine göre sıralamakta, rasyonel bir biçimde en iyi alternatifi seçerek karar vermekte ve yoluna devam etmektedir (Bakka ve Fivesdal, 1986: 171-178'den aktaran Tozlu, 2016: 36-37). Dolayısıyla ilgili modelde karar vericiler açısından ideal ve mükemmel koşulların varlığı ileri sürülmüş bu durum da eleştirilere neden olmuştur. Rasyonel karar verme yaklaşımına getirilen eleştiriler ile ortaya atılan sınırlı rasyonel karar verme modeline göre ise karar vericinin rasyonelliğini sinırlandıracak bazı faktörler söz konusudur. Bireylerin fiziki ve fizyolojik özellikleri, sahip oldukları değerler, bilgi ve veri edinme imkânlarının kısıtlılığı onların davranış, eylem ve kararlarını etkilemektedir (Tozlu, 2016: 37-38). Nitekim istenen sonuçlara ulaştıracak yolların, araçların ve imkanların seçimi sürecinde zihinsel, bedensel ve duygusal süreçler söz konusu olmaktadır (Eren, 2001: 171). Bir diğer ifade ile karar verme, salt teknik bir rasyonalite üzerinden işleyen, matematiksel hesaplamalara dayanan bir süreç değildir. Süreç üzerinde etkili olan değerler 
sistemi ya da kurumlar vardır (Önder, 2012: 5). Yol bağımlılı̆̆ı olgusu da sınırlı rasyonel karar verme sürecinin açıklanması noktasında açılımlar sağlama kapasitesine sahip olgulardan bir tanesidir.

Yol bağımlılı̆̆ı kavramı tarihsel kurumsalcılığın temel varsayımlarından bir tanesidir. Tarihsel kurumsalcılık "bireylerin kurumsal düzenlemeler içerisinde hareket ettikleri" fikrini benimsemektedir (Kay, 2005: 555). Konu üzerine önemli katkılar sağlayan yazarlardan biri olan Pierson'a (2000: 252) göre yol bağımlılığı geniş bir tanımlamayla "birbiri ardına gelen aşamaların arasındaki nedensel ilişkinin zamansal dizini" dir. Ona göre aşamalar arasında zamana yayılmış bir nedensellik bağı bulunması sebebiyle kurum, hem aktör davranışı hem de ileride ortaya çıkabilecek alternatifler üzerinde sınırlandırıcı bir etki yapmaktadır. Dolayısıyla tarihsel kurumsalcılık başlangıçta yapılan tercihin ya da oluşturulan yolun tamamen takip edilmesinden ziyade değişimin kaçınılmaz olduğunun kabulü ile bu değişimin izleyeceği güzergahın başlangıçta yapılan tercihler tarafından şekillendiğini öne sürmektedir (Peters, 1999: 64). Pierson'a (2000: 251) göre politik gelişmeler, kritik anlar ya da dönemeçler dolayısıyla şekillenir. Bunun sonucu olarak oluşan kurumsal örüntüler, farklı bir kurumsal tercihte bulunmanın alternatif maliyetinin yüksekliğinden dolayı da değişime direnç gösterebilmektedir.

Tarihsel kurumsalcılar, kurumsal örgütleri kolektif davranışları yapılandıran başlıca etmen olarak görmektedirler. Bir diğer ifade ile kurumlar ve bireysel davranışlar arasındaki ilişkinin önemine vurgu yapmaktadırlar (Hall ve Taylor, 1996: 5-7). Dolayısıyla yol bağımlılığının kavramsal çerçevesini çizebilmek için öncelikle kurum kavramının analiz edilmesi gerekmektedir. Kurum kavramı Hall ve Taylor (1996: 938) tarafından; örgütsel yapı içerisine gömülü resmi ya da gayrı resmi prosedürler, rutinler ve normlar olarak tanımlanmaktadır. Pierson (1993) pek çok kurumsalcının kurumların makro ya da anayasal boyutuna odaklandıklarını ancak kurumların 3 farklı boyutu olduğunu dile getirmiştir (aktaran Kay, 2005: 555):

a) Makro ya da anayasal boyut

b) Kolektif tercih ya da politika kararı boyutu

c) Bireysel kararların operasyonel boyutu

$\mathrm{Bu}$ çalışma kurumların kamu politikası boyutuyla ilgilenmektedir. Pek çok yazara göre politika bir nevi maksatlıdır (Heclo, 1972: 84; Friedrich, 1963: 79; Robinson, 1962: 3). Bir diğer ifade ile politika genel bir hedefler dizisini ya da istenen durumları ifade eder. Politika bir tercihtir, seçim olgusu ile ilgilidir. Eylem nedeninin seçimi, politika aracının seçimi, politika sonuçlarına nasıl cevap verileceğinin seçimi gibi pek çok tercih yapılmasını gerektiren bir süreçtir. Kurumlar ise farklıdır. İçselleştirilmiş alışkanlıklar ve rutinler söz konusudur. Politika ve kurum arasındaki bu kavramsal ayrım politika çalışmalarında yol bağımlılığının kullanımı açısından önemlidir (Kay, 2005: 556).

Yol bağımlılığı en yalın haliyle geçmişte yapılan tercihler neticesinde alınan kararların gelecekteki tercihler ve kararlar üzerindeki belirleyiciliğ̈ine vurgu yapan bir olgudur. İzlek bağımlılı̆̆ı, patika bağımlılığı gibi farklı şekillerde de kullanılan olgu, belirli bir politika tercihi yapıldığında kararların, süreçlerin ve olayların bu politikayı destekleyecek şekilde belirlenmesi ve her adımda alternatif bir politika belirleme olanağının giderek azalması olarak tanımlanır (Farral vd., 2014: 5-6). Ancak North'a (1990: 98-99) göre yol bağımlılığı geçmişin zarif bir şekilde geleceği öngördüğü bir kaçınılmazlık hikayesi değildir. Çeşitli kurumsal düzenlemeler etkisinde yapılan geçmişteki tercihlerin gelecekteki tercihleri kısıtlayan, tercih imkanları üzerinde baskı kurma süreci olarak değerlendirilmesi mümkündür. Kay’a (2005: 554) göre değişimin bir süre boyunca sınırlı kalması yola bağlı bir sürecin varlığını savunmak için yeterli değildir. Nitekim "sınırlandırılmamış" ancak istikrarlı bir seçim dizisi de bu gözlemle tutarlı olacaktır. Kısıtlı değişimi göstermek ve böylece yola bağlı bir süreci tanımlamak için gerçekleşmemiş olanın gerçekleşmeyeceğini yani bazı kararların daha önceki kararlar nedeniyle mümkün olmadığını da göstermek gerekmektedir.

Dinamik karar verme süreci tekrarlanan kararları gerektirir. Bu da aynı karar verme problemleriyle tekrar tekrar karşılaşılması anlamına gelir. Eğer bir karar verme sistemi daha önce var olan bir yolu takip ederse yapılan tercihin maliyetinin düşmesine ve faydasının artmasına neden olur. Ancak aynı zamanda madalyonun bir de diğer yüzü vardır. Bu da yapılan seçimlerin sürecin en başında kısıtlanmış olmamasına rağmen devam eden kararların kısıtlamalara yol açacağıdır. Tahmin edilebilir tercihler de etkili olmayan sonuçlara yol açabilir (Koch vd., 2009: 69).

Yeni kurumsal iktisatın da başvurduğu yol bağımlılığı olgusuna verilebilecek en basit ve somut örnek; artan getiri konusunda belirsizlikleri olan (artan getiriye sahip olmakla birlikte düzeyi noktasında belirsizlikleri olan) A ve B şeklinde adlandırılan iki teknolojiden B teknolojisinin şans eseri bir diğer ifade ile tesadüfi nedenlerle seçildiği bir durumda A teknolojisinin getiri durumu bilinmeden piyasada B'nin benimsenmesi ve gelecekte de firmaların B'yi benimsemesinin kolaylaşması durumudur. Bu varsayıma dayanarak ekonomi açısından, "piyasalar tarafından benimsenen verimsiz teknolojilere sahip olmak gibi" ilginç sonuçların ortaya çıkabileceği düşünülmektedir (Kay, 2005: 562). Yol bağımlılığı varsayımının ilgili teknolojik gelişme örneği 
ekseninde verimsizliklerin sürdürülebilir olması gibi bir sonuç üretmesi kamu politikaları açısından önemle değerlendirilmesi gereken bir durumdur (Kay, 2005: 567).

Scott Page'ye (2006: 88) göre yol bağımlılı̆̆ının birbiriyle bağlantılı dört farklı nedeni bulunmaktadır: Artan kazançlar, öz pekiştirme (kendini güçlendirme), olumlu geri dönüşler ve kilitlenme (lock-in). Page, bu nedenlerin birbiriyle bağlantılı olmakla birlikte farklı olduğunu dile getirerek tek tek açıklamıştır. Ona göre artan kazançlar, yapılan bir seçimden ya da gerçekleştirilen bir eylemden ne kadar çok yarar sağlanırsa o doğrultuda bir yol bağımlılığı olacağını ifade eder. Öz pekiştirme (kendini güçlendirme) ise yapılan bir seçimin ya da gerçekleştirilen bir eylemin, bu durumun devamını, sürekliliğini teşvik eden birtakım tamamlayıcı kurum veya gücü devreye sokması anlamına gelmektedir. Olumlu geri dönüşler ise, aynı seçimin ya da eylemin diğer insanlar tarafından yapılması durumunda olumlu dişsallıklar yaratarak bir yol bağımlılığına neden olmasını ifade etmektedir. Kilitlenme ile anlatılmak istenen ise yapılan bir seçimin ya da gerçekleştirilen bir eylemin yeterli sayıda insanın bu şekilde bir seçim yapması ya da eyleme geçmesi nedeniyle diğerlerinden daha iyi olarak algılanması anlamına gelmesini ifade etmektedir.

Karar verme sürecinde bir yolun oluşumunu aşağıdaki şekille açıklanmak mümkündür:

\section{Şekil 1: Karar Verme Sürecinde 'Yol'un Oluşumu}

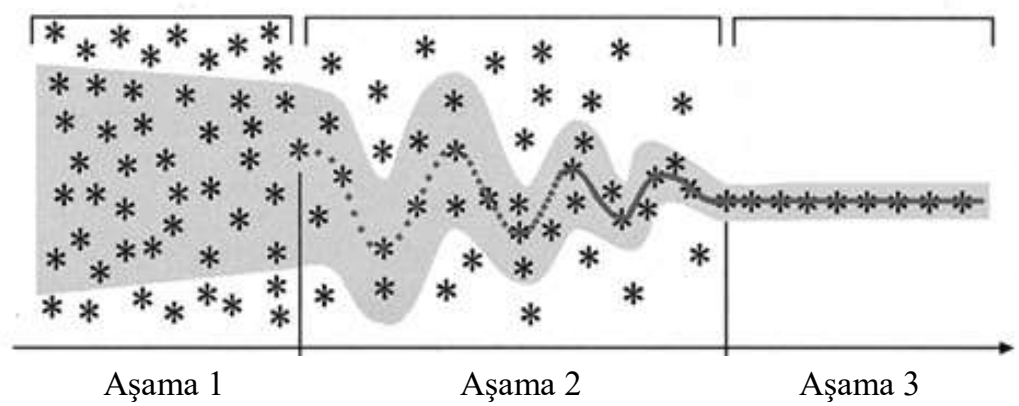

$$
\begin{aligned}
& * \quad \text { Alternatifler } \\
& -\quad \text { Oluşan yol } \\
& \square \text { Tercihe açık } \\
& \text { alternatiflerin } \\
& \text { derecesi }
\end{aligned}
$$

Kaynak: Sydow, Schreyögg ve Koch, 2009: 692

Modelin birinci aşaması beklenmedik bir durum ile karakterize edilir. Karar verme davranışının yönlendirilmediği ve tercihlerin sınırlandırılmadığı bu aşamada geçmişin izleri modelde gölge ile gösterildiği üzere seçimlerin daralmasına neden olabilir. Bu ilk aşama kritik dönemeç olarak adlandırılabilecek bir karar ya da kendini güçlendirme ile sona erer. $\mathrm{O}$ anda karar verme süreci belirli bir seçenek için olumlu geri bildirim tarafindan tetiklenen dinamik bir daralma sürecine girer. İkinci aşamaya geçildiğinde zaman içerisinde birtakım kararların tekrarlanması muhtemeldir. Kendini güçlendiren mekanizmalar sağlamlaşırsa ilk kararı yeniden üreten bir hareket etme şekli oluşur. İkinci aşamada alternatif tercih imkanları hala mevcuttur ancak gölge ile gösterildiği üzere gittikçe daha kısıtlı hale gelecektir. Üçüncü aşama ile birlikte yol kilitlenir ve baskın model belirleyici bir karakter kazanır. Karar süreci tamamen sınırlandırılmıştır. Diğer alternatifler daha verimli olsa bile göz ardı edilir. Kilitlenme durumunda karar verme sistemi başka bir alternatife geçemez. Bir rasyonalite kayması söz konusudur. Davranışsal bir etkilenme durumu ortaya çıkar. Ancak üçüncü aşamada bu durumun farkına varılırsa karar verme sisteminin kilitlenmemesi olasıdır. Böyle bir durumda karar verme sistemi daha cazip bir çözüme geçecektir. Yine de bir karar verme sürecinde önceki ve mevcut kararlar başarılı olarak algılanırsa böyle bir durum da zaten ortaya çıkmayacaktır (Koch, 2009: 70).

Yola bağımlı süreçlerin mantığı artan olumlu geribildirimler sağlamak ve farklı bir kurumsal tercihte bulunmanın alternatif maliyetinin yüksekliğinden dolayı (Pierson, 2000: 251) karar verme sistemini belirli bir yönde tetiklemektir. Yol bağımlılığının istenmeden ortaya çıkması durumunda ise kurumların, hem aktör davranışı hem de ileride ortaya çıkabilecek alternatifler üzerindeki sınırlandırıcı etkisi (Pierson, 2000: 251) gibi bilişsel süreçleri daha fazla ortaya çıkarmak zordur. Nitekim bu ancak karar vericileri bilişlerinden haberdar ederek mümkün olabilir ki bu da farkındalık yaratarak normalde alacakları karardan farklı kararları vermelerine neden olacaktır (Koch vd., 2009: 81-82).

\section{KAMU POLITIKKALARINA KARAR VERME SÜRECINDE YOL BAĞIMLILIĞI}

Kamu politikasının en bilinen tanımı "bir hükümetin yapmayı ya da yapmamayı tercih ettiği her şeydir". $\mathrm{Bu}$ tanımdan hareketle hükümetlerin tüm faaliyetlerinin yanı sıra beyan ederek duyurdukları niyetleri ve tüm hareketsizlikleri de kamu politikası kapsamında değerlendirilmektedir (Dye, 1972: 1-2). Ancak bu tanım her şeyin, kamu kurumlarının rutin işlerinin bile kamu politikası olarak algılanması sonucunun ortaya çıkmasına 
neden olabilmekte ve kamu politikalarının doğru anlaşılmasına engel teşkil edebilmektedir. Dolayısıyla "politika ile ilgili olarak kurumların yaptıkları seçimler" şeklinde yapılan tanımlama daha öze dair olacaktır (Çevik, 2016: 143). Kamu politikasına dair bu bakış açısı süreçteki "tercih" kavramını ön plana çıkarmaktadır (Sobacı, 2012: 52). Kamu politikaları ile ilgili çalışmaların büyük bir kısmında ise "tercihi kim yapar?" sorusuna cevap aranarak politikaların formülasyonu ve uygulanması sürecine müdahil olan aktörler analiz edilmiştir. Ancak "tercih sürecine etki eden unsurlar nelerdir?" sorusu da en az "tercihi kim yapar" sorusu kadar önem arz eder. İlgili aktörlerin bilinçli ya da bilinçsiz bir şekilde öngörülerine dayalı olarak politika seçeneklerinden birini seçtiğine inanmak Mitchell ve Mitchell'in (1969: 396) ifade ettiği gibi en kolay yoldur. Oysaki tercih olgusu ve karar verme süreci bu kadar kolay ifade edilebilecek durumlar değildir. Politika bilimi literatürü farklı disiplinlerden gelen öngörülerden yola çıkarak politika yapıcıların "önerilen bir politikanın ya da reform hareketinin kabul edilip edilmemesi noktasında tercih yaparken zihinlerinde neleri dikkate alacakları" sorusunu yanıtlamak için biraz eklektik bir yaklaşım benimsemiştir. Bu soruya verilen cevaplarda güç/çatışma, politik öğrenme, tarih, fikirler, politik uygulanabilirlik gibi farklı konulara vurgu yapılmıştır. Çatışma/güç modeli en yaygın kullanılan yaklaşımdır. Politika oluşumunu baskın güç yapısının/yapılarının çatışmasının bir ürünü olarak görmektedir. Alternatif olarak politikaları öğrenmenin bir ürünü olarak gören yaklaşım ise karar alma konusunda daha rasyonel bir bakış açısı benimsemektedir (Bennett ve Howlett, 1992). Uygulama yaklaşımı ise karar verilen politikanın neye etkisi olduğu ya da olacağı üzerinde durur (Li, 2009: 80). Politik öğrenme teorileri tarihin politika oluşturmadaki rolünü de tartışır. Geçmişin, şimdiki zaman ve gelecek üzerindeki etkisine vurgu yapar (Hirsch ve Gillespie, 2001: 79). Bu etkiyi temel alan yol bağımlılığı olgusu da süreci açıklamada başvurulabilecek, öngörülerinden yararlanılarak kamu politikaları yapbozunun eksik parçalarını tamamlamaya katkıda bulunabilecek olgulardan bir tanesidir (Gül, 2013: 86).

Bir kamu politikası anlık bir olay ya da karardan ziyade birbiriyle ilişkili birçok unsurun etkisinde oluşan karmaşık, bileşik bir değişkendir. Siyasa oluşum süreci literatürde çeşitli şekillerde formüle edilmiştir. James Anderson kamu politikası oluşum sürecini "problemi tanımlama, gündem oluşturma, politikanın formülasyonu, kabullenilmesi, uygulanması ve değerlendirilmesi” olarak sıralamıştır (Nelson, 1996: 555). İlgili sıralamaya benzer şekilde literatürde pek çok aşama ortaya konmuştur. Ancak 1970'lerin sonlarında kamu yönetiminde yaşanan değişim dalgası ile birlikte siyasa oluşum süreci de bir dönüşüm geçirmiştir. Küreselleşme, post-modernizm ve yeni kamu yönetimi baskısı kamu yönetiminde geleneksel karar verme anlayışını etkilemiş ve kamu politikalarında $3 \mathrm{E}$ olarak ifade edilen "ekonomikliği (economy), verimliliği (efficiency) ve etkililiği (effectiveness) sağlama amacı doğrultusunda karar verme sürecine pek çok aktör dahil olmuştur. Dolayısıyla kamu politikalarında arzulanan kriterlerin sağlanabilmesi için karar verme sürecine odaklanılması gerekmiştir. Bu noktada rasyonel karar teorileri duygulardan, değerlerden ve sezgilerden soyutlanmış ekonomik insan anlayışıyla ideal bir karar verme sürecinin olabilirliğine vurgu yapmıştır (Önder, 2012: 8-10). Ancak dikkate alınması gereken durumlardan biri de karar verme davranışını etkileyen önemli olgulardan biri olan karmaşıklıktır. Karmaşıklığın en önemli sonucu rasyonel karar alma modellerinin uygulanmasının artık mümkün olmadığı ya da "daha iyi” kararlara yol açmadığıdır. Örgütlerde kararların nasıl alındığını açıklayan ve analiz eden araştırmaların çoğunda kararlar rasyonel karar davranışının, rasyonel seçim teorisinin öngördüğü şekilde nadiren meydana gelir. Problemler tanımlanmamıştır, çözümler aranmaktadır ve değerlendirmeler de dolaylıdır. Gerçek dünyada karar vermeyi reçete etmek sorunludur. Sınırlı rasyonellik ve karmaşıklık madalyonun iki yüzü gibidir. İnsan zihni ve insan zihninin içinde faaliyet gösterdiği çevre birbirine bağımlıdır. Gerçek dünyada karar verme sistemleri sınırlı zamanla ve bilgiyle kısıtlıdır. Karmaşıklık karar vericiyi sınırlar. Bu nedenle gerçek dünyada karar vericiler bilgiyi değerlendirirken ve karar alırken bilişsel sezgilerine güvenir. Sezgisel davranma karmaşıklığı azaltmak için uygun bir stratejidir (Koch, 2009: 71).

Rasyonel karar vermeyi eleştiren isimler, rasyonelliğin mutlaklığına karşı çıkarak kararların değerlerden bağımsız olamayacağına vurgu yapmıştır. Sınırlı bir rasyonelliğin söz konusu olduğunu savunmuşlardır. Karar, siyasetçi ya da yönetici fark etmeksizin bir insan elinden çıkmakta ve bu da kararın içinde duygu ve heyecanların olma ihtimalinin her zaman var olacağının göstermektedir (Önder, 2012: 11). Kamu politikasına karar verme sürecinde de rasyonel karar vericilerden söz edebilmek için ortaya konulabilecek çok fazla standart yoktur. Nitekim standartların oluşturulması süreci de tercihlerin, değerlerin, anlayışların etkisinde kalacaktır. Dolayısıyla uzun ve karmaşık bir süreç sonucunda geliştirilen kamu politikaları ile ilgili sadece karar verme sürecine dair derinlikli bilgi üretilmesi sonuca ciddi katkılar sağlayacaktır (Çevik, 2016: 163-164). $\mathrm{Bu}$ doğrultuda yol bağımlılı̆̆ da kamu politikasında karar verme sürecini açıklamada ve politikaların oluşturulduktan sonra değiştirilmesinin ve reformun zor olabileceğine dair deneysel gözlemler ve bilişsel sezgiler noktasında önemli bir etiket sunar. Yol bağımlılığı politika kararlarının zaman içerisinde biriktiği ve politika yapıcıların seçeneklerini kısıtladığı öngörüsünü kapsar (Kay, 2005: 558). Kamu politikalarına karar verme sürecinde yol bağımlılı̆̆ ile iki farklı şekilde karşılaşılabilir (Kay, 2005: 564): 
a) Politikanın amaçlarını, araçlarını ve doğasını belirleyen "fikirlerde ve standartların çerçevesinde" bir yol bağımlılı̆̆1 (Hall, 1993),

b) Herhangi bir eksik bilgi durumundan kaynaklanmamakla birlikte karar alma sürecinde incelenen olas alternatif eylem biçimlerinin sınırlı olduğu yol bağımlılığı (Pritchard, 2002).

Bütün politika sistemi içerisinde politikaların oluşturulması ve uygulanması noktasında etkili olan aracıların karar vermesinde rol oynayan kurumlar vardır. Kamu politikalarını sadece politika sürecinde etkili olan bireysel karar vericilere indirgemek doğru değildir. Nitekim kamu politikalarında yol bağımlılığını anlamak açısından geçmiş kararlarda etkili olan kurumları da ele almak gerekmektedir. Bu kurumlar, süreçte rol alan aktörlerin fikirlerini ve bu doğrultuda da mevcut durumdaki politika seçeneklerini sınırlandırabilir ya da şekillendirebilir (Kay, 2005: 557).

Kamu politikaları açısından yol bağımlılığının varlığının analiz edilebilmesi için genellikle politikalardaki değişim ve süreklilik olgularına başvurulmaktadır. Nitekim yol bağımlılığı varsayımına göre kurumlar belirli bir politika tercihi yaptıklarında kararlarını, süreçleri ve olayları bu politikayı destekleyecek şekilde belirledikleri ve her adımda alternatif bir politika belirleme şansı giderek azaldığı (Farral vd., 2014: 5-6) için tercih edilen politikanın uzun süre değişmeden aynı yol (path) üzerinde kalması noktasında bir direnç gösterme eğilimindedir. Söz konusu yolun değişebilmesi için değişim konusunda büyük bir baskıya ihtiyaç vardır (Arabac1, 2008: 76). Dolayısıyla yol bağımlılı̆̆ı istikrarı açıklamada değişimden daha iyidir (Kay, 2005: 565566). Bu noktada yol bağımlılığının kamu politikalarındaki etkisini açıklamak adına istikrarın ya da değişimin gözlemlenebileceği “analiz seviyesi olarak neyin alınacağı” sorusu gündeme gelmektedir. Politik bir analiz için farklı politika ölçeklerinin kullanılması politikaların sürekliliği ve değişimini ortaya koyacak kesin bir çerçevenin bulunmamasındandır. Politika değişimine karar vermek zordur. Çünkü makro politikada bir istikrar olsa bile alt sistem ya da politika programı seviyesinde bir değişim söz konusu olabilir (Kay, 2005: 557). Hall (1993: 278-279) 3 farklı seviyede politika değişimi öngörmektedir:

a) Politika araçlarının düzeyinde değişim (Birinci düzey değişim)

b) Kullanılan politika araçlarında değişim (İkinci düzey değişim)

c) Genel politika paradigmasında değişim (Üçüncü düzey değişim)

Hall'un çalışması "nesnedeki (politika araçları ve onların düzeylerindeki) değişim (change in things)" ile "nitelikteki (politika paradigmasındaki) değişim (change in kind)" arasındaki farkı ortaya koyar. Bu da mevcut politikanın değişip değişmediğini ya da yeni bir politikaya geçilip geçilmediğinin değerlendirilmesi için bir çerçeve sağlar (Kay, 2005: 557). Kamu yönetimleri tarafından orijinal politikaların sonuçlarını hafifletmek için yapılan "yama" ya da "düzeltme" şeklinde eklenen yeni politikalar nesnedeki politika değişimine örnek olmakla birlikte politika alt sistemlerdeki bir diğer ifade ile nitelikteki yol bağımlılığını açıklamaya katkıda bulunan bir örnektir (Kay, 2005: 567).

"Yol bağımlılığından nasıl kaçınılır" sorusu da özellikle söz konusu olguyu rasyonaliteyi sınırlandıran, verimsizlikleri yayan bir olgu olarak değerlendirenler için önem arz eden sorulardan bir tanesidir. Nitekim yol bağımlılığı için, kamu politikasına karar verecek olan aktörlerin rasyonalite ihlali yapmaları gerektiğini savunurlar. Rasyonalite ihlali yol bağımlılığının varlığı için gerekli ve yeterli bir kriterdir. Onlara göre rasyonel birey yol bağımlılığından kaçınabilirken, sınırlı rasyonel birey bunu başaramaz ve yola bağımlı olmaya açıktır (List, 2004: 510). Bunun yanı sıra savundukları bir diğer görüş; bireylerin kendilerine dayatılan bir rasyonellik disiplini ile yola bağımlılıktan kaçınmaya çalışsalar da bunun gruplar için geçerli olamayacağıdır. Yola bağımlılık özellikle kolektif düzeyde ciddidir. Tutumlarını üyelerinin görüşlerine göre belirleyen herhangi bir grup mutlaka yol bağımlılığı olarak nitelenebilecek rasyonalite ihlalleri riskine açıktır (List, 2004: 510-511). Kamu politikaları da katılımı gerektiren kolektif bir eylem (Usta, 2013: 81) olarak ele alındığında söz konusu varsayım ciddiyetle değerlendirilmesi gereken bir durumdur. Ancak etkili bir reform ya da politika için kamu politikalarına karar verme sürecinde yol bağımlılığını ilgili aktörlerin önünde bir engel olarak değerlendirmek ve yola bağlı bir süreç olmadan politikaların "daha iyi” sonuçlar üreteceğini söylemek de bu çalışmanın aşırı yorumlamas1 (Kay, 2005: 568) olacaktır.

\section{SONUÇ}

Kamu politikaları, toplumsal sorun ya da ihtiyaçların varlığının tespitinden, üretilen çözümlere yönelik geri bildirime kadar uzanan geniş bir yelpazede hayat bulan karmaşık bir süreçtir. Karar verme ise bu sürecin kalbi konumundadır. Geçmişle, şu anla ve gelecekle ilgili olan karar verme olgusu özellikle toplumsal sonuçlar üreten kamu politikaları açısından titizlikle ele alınması gereken aşamalardan bir tanesidir. Karar aşamasında dikkate alınacak unsurlar çeşitli matematiksel hesaplamalar sonucunda elde edilebilecek somut göstergeler değil, kamu yararıdır. Bu nedenle teknik bir rasyonaliteye dayanan karar verme aşamasından ya da belirli standartlar çerçevesinde ilerleyen bir kamu politikası sürecinden bahsetmek zordur. İnsan elinden çıkan tüm 
kararlarda olduğu gibi kamu politikalarında da karar vericilerin tercihleri üzerinde etkili olan farklı unsurlar bulunmaktadır. Bu unsurlar hakkında derinlikli bilgi edilmesi de karmaşık kamu politikaları sürecine ciddi katkılar sağlayacaktır. Bu doğrultuda çalışmada, tarihsel kurumsalcılığın önemli varsayımlarından biri olan yol bağımlılığı çerçevesinde kamu politikalarında karar verme sürecinin yeniden değerlendirilmesi amacı güdülmüştür. Nitekim rasyonel karar verme modellerinin sorgulandığı günümüzde sınırlı rasyonelliği açıklamada yararlanılabilecek önemli olgulardan bir tanesidir. Bu doğrultuda çalışma çerçevesinde öncelikle karar verme olgusu ve yol bağımlılığı varsayımı irdelenmiş daha sonra ise kamu politikası sürecinde karar verme aşaması yol bağımlılı̆̆ ekseninde değerlendirilmiştir.

Geçmişte yapılan tercihlerin ya da verilen kararların gelecekteki tercihler ve kararlar üzerinde belirleyici olduğu ve bu belirleyiciliğin derecesinin geçmişteki karar doğrultusunda atılan her adım sonrasında giderek artacağı varsayımına dayanan yol bağımlılı̆̆ olgusu kamu politikalarına karar verme sürecinde yapılan tercihlerin arka planını okumada başvurulabilecek önemli bir varsayımdır. Geçmiş karar ve tercihlerin ya da karar vericilerin fikirlerini sınırlandıran kurumların etkisinde var olan bir yol bağımlılı̆̆ının, toplumsal bir sorun ya da ihtiyaç karşısında ileri sürülebilecek alternatifleri sınırlandırma noktasında negatif bir rol oynayacağı bir diğer ifade ile rasyonel bir şekilde en iyi ya da en uygun alternatiflerin oluşturulmasının ya da seçilmesinin önünde engel teşkil edeceği şeklinde bir değerlendirme yapmak mümkündür. Ancak duruma farklı bir açıdan bakıldığında söz konusu yol bağımlılığının olumlu geribildirimler sağlayan bir süreçte karmaşıklık ve maliyet azaltıcı etkisi de göz ardı edilemez. Zamansal ve ekonomik açıdan kısıtlı bir alanda üretilmesi gereken kamu politikaları açısından özellikle benzer problemlerle karşılaşıldığında var olan bir yolun izlenmesi önemli yararlar sağlayacaktır. Dolayısıyla kamu politikalarına karar verme açısından yol bağımlılığı olgusunu salt olumsuz ya da salt olumlu şekilde değerlendirmek anlamlı sonuçlar üretmeyecektir. Kolektif bir eylem olarak kamu politikalarının yol bağımlılı̆̆ına açık bir alan olduğu bilinerek karar verme aşamasında madalyonun iki yüzünün de dikkatli bir şekilde değerlendirilmesi süreci açıklama noktasında önem arz etmektedir. 


\section{KAYNAKÇA}

Arabacı, A. (Bahar 2008). “Avrupa Birliği'nde Çıkar Temsilinin Gelişimi”. Uluslararası İliş̧kiler, 5 (17), 73-103.

Bennett C. J., ve Howlett, M. (1992). "The Lessons Of Learning: Reconciling Theories Of Policy Learning And Policy Change", Policy Sciences, (25), 275-294.

Çevik, H. H. (2016). "Karar Verme Süreci”. (Ed: H. Altunok, F. G. Gedikkaya), Kamu Politikaları Ansiklopedisi. Nobel Yayınevi, Ankara.

Dye, T. R. (1972). Understanding Public Policy. Englewood Cliffs. Prentice Hall, New Jersey.

Eren, E. (2001). Yönetim ve Organizasyon, Beşinci Baskı. Beta Yayınevi, İstanbul.

Ergun, T. (2004). Kamu Yönetimi: Kuram, Siyasa, Uygulama. TODAİE Yayınları, Ankara.

Farrall, S., Gray E., Jennings W. ve Hay C. (January 2014). "Using Ideas Derived from Historical Institutionalism to Illuminate the Long-term Impacts on Crime of 'Thatcherite' Social and Economic Policies: A Working Paper". https://www.sheffield.ac.uk/polopoly_fs/1.339300!/file/WorkingPaper1HistoricalInstitutionalism.pdf, (Erişim Tarihi: 17.02.2018).

Friedrich, J. C. (1963). Man and His Government. McGraw-Hill, New York.

Gül, Z. (2013). Kamu Politikasında Kurumsallık (Institutionalism) Teorisi. (Ed: A. Kaptı), Kamu Politikası Süreci. Seçkin Yayıncilık, Ankara.

Hall, P. A. (1993). "Policy Paradigms, Social Learning, and the State", Comparative Politics, 25 (3), 275-296.

Hall, P. A. ve Rosemary C. R. T. (1996). "Political Science and the Three New Institutionalisms", Political Studies, 44 (4), 936-957.

Hall, P. A. ve Rosemary C.R. T. (1996). "Political Science and the Three New Institutionalisms", MPIFG Discussion Paper, 96 (6), 3-32.

Heclo, H. (1972). Review Article: Public Policy. British Journal of Political Science, 2 (1), 83-108.

Hirsch P. ve Gillespie J. (2001). "Unpacking Path Dependence: Differential Valuations Accorded History Across Disciplines", (Ed: R. Garud ve P. Karnøe), In Path Dependence and Creation, Lawrence Erlbaum Ass, Mahwah, $69-90$.

Kay, A. (2005). "A Critique of the Use of Path Dependency in Policy Studies", Public Administration, 83 (3), 553-571.

Koch, J., Eisend M. ve Petermann A. (2009). "Path Dependence in Decision-Making Processes: Exploring The Impact Of Complexity Under Increasing Returns", Business Research, 2 (1), 67-84.

Kutlu, Ö. ve Özdemiray S. M. (2016). "Politika Transferine Karar Verme Süreci”. Sayıştay Dergisi, (101), 79-95.

Li, C. L. (2009). "Decision-Making in Chinese Local Administrative Reform: Path Dependence, Agency And Implementation", Public Administration and Development, 29, 79-87.

List, C. (2004). "A Model of Path-Dependence in Decisions over Multiple Propositions", American Political Science Review, 98 (3), 495-513.

Mitchell, J. M. ve Mitchell W. C. (1969). Political Analysis \& Public Policy: An Introduction to Political Science, Rand McNally Company, Chicago.

Nelson, B. J. (1996). "Public Policy And Administration: An Overview", (Ed: R. E. Goodin ve H. Klingemann) A New Handbook of Political Science, Oxford University Press, Oxford, 551-592.

North, D. C. (1990). Institutions, Institutional Change and Economic Performance. Cambridge University Press, Cambridge.

Önder, Ö. (2012). "Karar Verme: Kamu Yönetimi Ve Siyaset Bilimindeki Anlamı/ Önemi”. (Ed: Ö. Önder ve F. Kırışık), Kamu Yönetimi ve Siyaset Biliminde Karar Verme. Orion Yayınevi, Ankara.

Page, S. (2006). "Path Dependence". Quarterly Journal of Political Science, 1 (1), 87-115.

Peters, B. Guy (1999). Institutional Theory in Political Science: The New Instutionalism. London: Pinter.

Pierson, P. (1993). "When Effect Becomes Cause: Policy Feedback and Political Change", World Politics, (45), 595- 628.

Pierson, P. (2000). "Increasing Returns, Path Dependence, and the Study of Politics", American Political Science Review, (94), 251-267.

Pritchard, D. (2002). “Are Economic Decisions Rational? Path Dependence, Lock-in and 'Hinge' Propositions”, Reason in Practice, 2 (3), 31-45.

Robinson, J. (1962). Congress and Foreign Policy Making. Dorsey Press, Illionis.

Sobacı, Z. M. (2012). Bir Kamu Poltikası Aktörü Olarak Bürokrasi: Türkiye Üzerine Değerlendirmeler. (Ed: Ö. Önder ve F. Kırışık), Kamu Yönetimi ve Siyaset Biliminde Karar Verme. Orion Yayınevi, Ankara.

Sydow, J., Schreyögg G. ve Koch J. (2009). "Organizational Path Dependence: Opening the Black Box", Academy of Management Review, 34 (4), 689-709.

Tozlu, A. (2016). "Karar Verme Yaklaşımları Üzerinde Herbert Simon Hegemonyası", Sayıştay Dergisi, (102), 27- 45.

Usta, A. (2013). "Kamu Politikaları Analizine Kuramsal Bir Bakış", Yasama Dergisi, 24 (2), 78-102. 